\title{
CHALLENGES AND OPPORT UNITIES IN GRADUATE NURSING EDUCATION BY DISTRIBUTED LEARNING IN CANADA AND BRAZIL
}

\author{
A nita M OLZAHN ${ }^{\text {a }}$ \\ Marjorie MACDONALD ${ }^{b}$ \\ Elizabeth BANIST ERc \\ LaureneSHEILDS \\ RosalieSTARZOM SKI \\ $M$ arilyn BROW N \\ Lucia GAM ROT H ${ }^{f}$ \\ Lisiane Girardi PASKU LIN ${ }^{9}$ \\ Denise Tolfo SILVEIRAg
}

\begin{abstract}
ABST RACT
In this paper, the authors share their experience related to graduate nursing programs offered by distributed learning ( $\mathrm{CL}$ ) in Canada and Brazil. A Ithough deg rees offered by DL are often the subject of criticism, the authors' experience has been that learning outcomes have been very good. Nevertheless, a number of challenges and opportunities have been encounter ed including those associated with flexibility of the prog ram, delivering practice courses at a distance, facilitating interaction, faculty workload and preparation and student support, $\mathrm{N}$ ewer technologies that may assist in this effort are identified. D espite the challenges encountered, students rate the program highly and ongoing efforts are underway to ensure excellence of such flexible innovative graduate programs in nursing. The authors argue that despite the challenges, DL programs offer high quality graduate education that meets the needs of many nurses.
\end{abstract}

Descriptors: E ducational technology. E ducation, distance. E ducation, nursing, graduate.

\section{RESUMO}

$N$ este trabalho, os autores partilham suas experiências na pós-graduação em E nfermagem no Canadá e B rasil ofer ecidas por meio de aprendizagem distribuída (AD ). E mbora a AD seja freqüentemente objeto de críticas, a experiência dos autores tem sido de resultados positivos. $N$ o entanto, uma série de desafios eoportunidades édiscutida, incl uindo: flexibilidade do programa, possibilidade de oferecimento de cursos práticos à distância, necessidade de facil itar a interação professor/ alunos, sobrecarga de trabal ho dos docentes, preparo dos docentes para este tipo de atividade eapoio aos estudantes. N ovas tecnologias que podem apoiar o desenvolvimento da AD são apresentadas. A pesar dos desafios identificados, os estudantes avaliam positivamente a AD eesforços tem sido feitos para assegurar, demodo inovativo eflexível, a excelência de programas de pós-graduação em enfermagem. 0 s autores argumentam queapesar dos desafios existentes, os programas de $A$ D oferecem alta qualidade para 0 ensino de pós- graduação na área de enfermagem eatendem às necessidades de muitos enfermeiros.

Descritores: T ecnologia educacional. E ducação à distância. E ducação de pós- graduação em enfermagem.

Título: D esafios eoportunidades na educação de pós- graduação em enfer magem por aprendizagem distribuída no Canadá e Brasil.

\footnotetext{
a Registered N urse (RN), PhD (D octor of Philosophy), Professor and D ean, F aculty of Nursing, U niversity of Alberta, Edmonton, Alberta, Canada.

${ }^{b} \mathrm{RN}, \mathrm{PhD}, \mathrm{Associate}$ Professor, School of N ursing, U niversity of Victoria, Victoria, British Columbia, Canada.

' RN , PhD, Professor, School of N ursing, U niversity of Victoria, Victoria, British Columbia, Canada.

dRN, PhD, Associate Professor, School of N ursing, and A ssociate D ean, Faculty of Human and Social D evelopment, U niversity of Victo-

ria, Victoria, British Columbia, Canada.

e M aster of Education, Program M anager, Faculty of Human and Social Development, Victoria, British Columbia, Canada.

${ }^{f} \mathrm{RN}, \mathrm{PhD}$, Professor Emerita, School of N ursing, University of Victoria, Victoria, British Columbia, Canada.

${ }_{9}^{9}$ RN, PhD, Professor, School of Nursing, Federal U niversity of Rio Grande do Sul, Porto Alegre, Rio Grande do Sul, Brasil.
} 


\section{RESUMEN}

E n este artículo, los autores comparten sus experiencias de programas de postgrado de enfermería, ofrecidos en Canadá y B rasil, el aprendizaje distribuido (AD ). A unque el AD sea objeto de críticas, la experiencia de los autores ha demostrado resultados positivos del a prendizaje. Sin embargo, se han encontrado al gunos retos y oportunidades: los relacionados con la flexibilidad del programa, la posibilidad de ofrecimi ento de cursos prácticos a distancia, la necesidad de facilitar la interacción profesor/ estudiante y a poyo a los estudiantes, la sobrecarga de trabajo del profesor y la necesidad de su preparación para esta actividad, $\mathrm{N}$ uevas tecnologías que pueden a poyar el desar rollo del AD son presentadas. A pesar de los desafíos identificados, los estudiantes evaluaron positivamenteel AD y se esfor zaron para asegurar, de manera innovadora y flexible, la excelencia de postgrado en enfermería. L os autores sostienen que a pesar de los desafíos, los programas de postgrado con el AD ofrecen educación de alta calidad y cumple las necesidades de muchas enfermeras.

Descriptores T ecnología educacional. E ducación a distancia. E ducación de postgrado en enfermería.

Título: R etos y oportunidades en la educación de postgrado en enfer mería por aprendizaje distribuido en Canadá y B rasil.

\section{INTRODUCTION}

$M$ any Canadian and Brazilian nurses are seeking opportunities for flexible graduate education programs, regardless of whether they live in urban or rural environments. Distributed learning $(D L)$ strategies enable students to engage in education whether at home, in the classroom, or in nursing practice settings. G eographical distance can be over come with technology to support students and faculty members in the education process. In this paper, the authors use the ter minology of distributed instead of distance learning because it has a broader application, includes use of technology in a variety of learning situations and takes into consideration the learning environments described in these settings.

$M$ any consider the reputation of $D L$ programs to be questionable. There is a pervasive attitude among educators that all meaningful learning should continue to take place in the classroom ${ }^{(1)}$. W hile less than satisfactory D L programs do exist, there is evidence that distance learning, particularly computer-mediated learning, results in improved learner effectiveness ${ }^{(2)}$. Students exposed to computer-mediated learning performed better than students in conventionally taught courses. E-learning, which is often used in DL programs, can promote educational diversity, create an environment in which there is greater opportunity and freedom to learn provided there is sufficient attention to maintaining educational standards ${ }^{(3)}$.

In this paper, we share our experience with $D L$ at a graduate level in Canada and Brazil. We review some of the challenges and opportunities associated with flexibility of the program, offering practice courses at a distance, faculty workload and preparation, facilitating interaction, and student support. We argue that, despite the challenges, D L programs offer high quality graduate education that meets the needs of many nurses.

\section{THE CONTEXT}

In Canada, several universities, including the U niversity of Victoria (UVic), offer M aster of N ursing (M N) programs via DL. T he U niversity of Victoria School of Nursing has offered an M N degree through DL since 2003. Today, three options are available, one in Advanced Practice L eadership (APL), another for $N$ urse Practitioners (NP), and a third newer option for Nurse E ducators. Our focus in this paper will be on the APL and NP programs, given that the Nursing $E$ ducation option was only recently started. Students in all three programs are required to attend a three day onsite orientation prior to beginning their program. N P students are also required to attend two one-week and onetwo-week onsite experiences during their program. T he M N program for N urse $E$ ducators is currently offered in $D L$ formats with some face-to-face w orkshops.

There are currently 131 students registered in the UVic M N Program, including 124 females and 7 males. M ost graduate students are midcareer professionals who are employed, many on a full time basis. The NP option is restricted to nurses with a Bachelor of Science in N ursing degree living in the Province of British Columbia. The APL option is open to nurses across Canada. T he D L E ducation option began as a pilot project funded by the federal government; expansion of this option is currently underway. 
The experiences with $D L$ are more limited in Brazil than in Canada. In nursing graduation programs, DL started in $2000^{(4)}$. The Federal University of Rio Grande do Sul School of $N$ ursing offered a DL program for nurses called Pedagogical Training Course in $\mathrm{H}$ ealth Professional Education from 2002 to 2005; this course was funded by the federal government and was integrated with 45 other universities in Brazil and coordinated by the Osvaldo Cruz Foundation (FIOCRUZ), an institution with experience in $\mathrm{DL}$, and the Federal $\mathrm{M}$ inistry of $\mathrm{H}$ ealth. $\mathrm{A}$ total of 290 students completed a 660 hour long program, consisting of two courses. M ost graduate students were women $(93.15 \%)$, with full timejobs $(95.00 \%)$, and were employed in schools to preparelicensed practical nurses. T he program was open to nurses across Rio G rande do Sul Province.

\section{FLEXIBILITY FOR ST UDENTS}

$M$ any students choose $\mathrm{DL}$ programs because of the flexibility of offerings. These flexible options allow students to fit their study within the context of their busy lives (work, home, family) as well as to access programs while minimizing the need to travel/ move to obtain graduate education. H owever, these same attributes may negatively impact timely program completion. T heU V ic APL option, in Canada, enables many students to complete course work on a part-time basis, to accommodate their busy professional and personal lives, but the NP option is more structured and less flexible, which tends to support more rapid student completion, despite the heavier course load and additional practice requirements. In Brazil, the flexibility is essential for course development because most of the students are nurses working while at the same time looking for an opportunity to obtain an educational credential.

\section{PART-TIME VERSUSFULL-TIME STUDIES}

At the U Vic School of N ursing, part-time and full-time studies are available. P reference is given to students taking full-time studies since most classes are small, and it is not financially feasible to run multiple sections of courses per year to accommodate the varied needs of part-time students. Although it was expected that full-time students would complete the program in slightly over two years, time to completion for most students was the full five years al lowed by the univer sity to complete the program. Further, we found that many students who initially registered as full-time students changed to part-time status.

At Federal U niversity of Rio G rande do Sul School of Nursing only part-time studies were available. T ime to completion for the program (two courses) was 11 months and approximately $75 \%$ students completed the courses on schedule.

\section{CHALLENGES OF OFFERING PRACTICE COURSES AT A DISTANCE}

The Canadian (UVic) M N program includes significant practice components and the School of Nursing employs a Practicum Coordinator who works with students and faculty members to find appropriate preceptors and placements. In the practicum, students are supervised on a day-to-day basis by the preceptor. T he faculty member visits or tel ephones both the student and preceptor on a regular basis and is responsible for evaluation of the student. However, there are many challenges in finding enough suitable preceptors and offering practice supervision by a faculty member, particularly if the student is not strong.

In both the APL and NP options, it has been difficult to locate preceptors in rural or in urban communities where there are few advanced practice nurses. Also, since we do not allow students to w ork with preceptors from their place of work (because of potential conflicts of interest and power imbalances), some are required to travel to other communities. Students can, however, practice in their own agency if they are able to work with a preceptor in a different program or unit. Students are responsible for arranging their own hours of practice at times that are mutually agreeable. D espite the challenges, we have been able to find placements for all students in each practice course.

In the NP option, adequate practice oversight by a faculty member is required. Considering this requirement, the admissions of $N P$ students are restricted to the province of the $U$ niversity.

To facilitate student supervision at a distance and to provide opportunities for greater interaction, weekly or bi-weekly practice seminars using Elluminate software were introduced; this enables synchronous interaction. In these seminars, students present cases to other students using 
PowerPoint software. T heinstructor augments the material in a class-like format. Students reported this W eb-based learning system to be very helpful in enhancing their learning.

In the APL option, instructors check in regularly with students during the academic term by telephone and e-mail. At the end of the term, a teleconference is arranged with the instructor, preceptor and student to conduct the students' final evaluation. Other meetings are also held throughout the term if required or requested by the instructor, the student, or the preceptor. Although the preceptor provides feedback during the evaluation process, the instructor is responsible for assigning the final grade.

In Brazil, the Pedagogical Training Course in $\mathrm{H}$ ealth Professional Education was launched by the government for nurses who either teach or would like to teach licensed practical nurses. $M$ anuals for the course were prepared by experts. Some faculty members, with masters or doctoral degrees from Brazilian federal universities, were tutors, and each regional area had a coordinator. These tutors offered learning support to the students who wanted to improve their competencies. The pedagogical approach is based on a reflexive and critical approach of reality ${ }^{(5)}$.

T he course involved 640 hours at a distance and 20 hours of face to face instruction. The face to face hours included an initial seminar at the beginning of the course to orient the students to the course material and future contacts at a distance. Final tests and a seminar to present student papers were held in a face to face format. The supervision at a distance was done by telephone, e-mails and instant messaging discussions (throughM SN). Some faculty members used tools such as N et M eeting for discussions related to learning activities proposed in the manual.

\section{INTERACTION BETWEEN ST UDENTS AND FACULTY MEMBERS}

W hile distributed learning offers the benefit of accessibility, it is easy for electronic communication to be impersonal and there is a risk that students will have less access to faculty members. Interpersonal interaction is central to meaningful learning and to students' knowledge construction.

In both countries, specific efforts were made to create a relational on-line lear ning environment, make initial and ongoing on-line connections, and foster dialogue for effective engagement. In virtual learning environments, a wide variety of skills and pedagogical strategies are needed to facilitate students' connection with the instructor. Instructor immediacy or interactions with students that express warmth and closeness translate into effective learning ${ }^{(6)}$. A supportive on-line learning environment facilitates discussion in which students share deeply held values and examine complex issues from a variety of perspectives. M oreover, an on-line learning community is important for breaking down student isolation and fostering effective learning ${ }^{(7)}$.

In both the Canadian and Brazilian experiences, success of the courses requires specific considerations. T he instructors' initial contact with students sets the tone for a positive learning environment. D uring this time, it is important that students share information about their area of practice and research interests with the instructor and the entire student group. We have found it effective to have students include some information about their personal contexts given that many are geographically distant from one another. This introductory activity helps the instructor establish rapport with each student and helps students connect with the larger group. Following submission of students' descriptions, the instructor sends an individually crafted welcome message that conveys interest in their learning. The time invested in these initial activities is important for reducing students' fears about DL and for enhancing their engagement in the course materials.

Once the initial instructor/learner contact has been established, it is essential to set the stage for regular communication that is visible, flexible and accessible. Instructor availability is the cornerstone for student learning whether by individual telephone, face-to-face or e-mail communication $^{(7)}$. Prearranged regular times for student contact can help build and sustain rapport. T he use of a variety of on-line modalities congruent with the course design and students' learning needs enhances instructor/learner communication. Such modalities can be asynchronous (e.g., e-mail, Blackboard, M oodle, podcasts) and/ or synchronous (instant messaging, chat rooms, web cams, teleconference, Elluminate). Synchronous communication, however, presents challenges of accommodating students in different time zones across the country ${ }^{(4,7)}$. 
Dissatisfaction with $D L$ has been linked to slow turn around for instructor feedback(8). Feedback on group or individual work needs to have a short turnaround (within at least two to three days) to facilitate positive student/ instructor interactions. T imely individual e-mails that offer constructive feedback and acknowledge students' strengths can promote students' confidence in learning. Feedback on written papers may take longer, depending on the number of students in the class and whether the instructor returns assignments electronically or by mail.

Posing questions throughout the course is a key strategy to foster student-instructor and peer interaction. Q uestioning can also help students develop their voice and skills in critical analysis. For example, through questioning, instructors can demonstrate how to draw upon and integrate current literature and model ways that students can expand their reflexive capacity with peers and with clients. We suggest questions such as the following for encouraging such critical analysis: You might consider ... Do you agree with [ M ary's] view [ on this topic] and why? Using [ M ary's] framework described in your course readings, how did you come to this understanding of ... ? W hat influence has your practice had on this point of view? In what way?

Through reflective questioning, students have the opportunity to gain cognitive skills in exploring and critiquing current conceptualizations ${ }^{(9)}$. O ccasionally on-line student discussion can become fragmented, tangential or unfocused. Strategically placed questions can re-orient the discussion and build bridges for greater student involvement.

Car eful listening is essential in the electronic environment as it can be easy to misinterpret an individual's intent; listening can be demonstrated through reading, responding, and seeking clarification regarding individual student postings. E motional expression is frequently difficult for students and instructors to communicate on-line. A non-judgmental approach to listening is inte$\mathrm{gral}$ to this mode of communication. Students are encouraged to clarify and ask open-ended questions to check the accuracy of their interpretations. $U$ sing personal concrete examples in learning activities can also contribute to the interpersonal aspects of the on-line learning environment. Examples provide meaningful ways for students to engage with each other and with the instructor.
For example, in a graduate research course, one co-author used specific examples from her field work to describe some of the ethical dilemmas she encountered in her research. T hese examples fostered discussion, made explicit some of the dilemmas in field work explicit, and provided a forum for students to ask questions.

Engagement in virtual environments allows for the co-construction of knowledge and facilitates cross-pollination of ideas ${ }^{(7)}$. T his dialogical approach to learning allows students to engage in a process of knowledge construction with peers. By threading discussions, instructors and students can track the development of ideas so the cocreative process is evident. This learning occurs more explicitly than is usually evident in face-toface environments. On-line communication, when used creatively and in ways that are pedagogically sound, creates a responsive environment for learning.

\section{FACULTY WORKLOAD AND PREPARATION}

There are differing opinions as to whether teaching on-line increases workload for faculty as compared to teaching in a classroom. D rawing on time records from a larger study it was noted that there were no statistically significant differences in teaching time requirements between 11 webbased and five face-to-face graduate level nursing courses, but the way that time was spent differed, with more time spent on interaction, on average, in the web-based courses ${ }^{(10)}$. In another study ${ }^{(11)}$, the communication time between instructor and student in the DL course was $29 \%$ greater than in the classroom format. M ore importantly, the communication pattern in the $D L$ format involved much more individual communication between instructor and student than in the classroom, where the bulk of the communication was in the large group. W hen the distance cour ses were packaged with course notes, lear ning activities, assignments, and readings, the instructor may have less class preparation, other than familiarizing her or himself with the notes and the readings before going online. This format also ensures a certain consistency in curriculum del ivery. On the other hand, teaching a pre-packaged course means that instructors who are not the course writers do not have the same academic freedom as the writer to teach content 
or use learning activities they believe would be more relevant for the students. Course updates and revision can take considerable time and financial resources. A t UVic, we are currently in the process of a major curriculum revision in which we will no longer provide pre-packaged course materials. Instructors will now develop their course materials and offer them week by week, in much the same way as they do for classroom-based teaching.

As noted earlier, creating a relational on-line learning environment is very important and many faculty members perceive a demand for intensive on-line engagement. However, it is possible to overdo instructor postings. W hile some authors argued that instructor responsiveness has a crucial place in a successful learning and student satisfaction $^{(12)}$, others, found that less instructor intervention resulted in better quality and more extensive student postings ${ }^{(13)}$. It was concluded that students contribute more to discussion forums and pursue discussion threads at greater length if instructors intervene in a minimal way, although students themselves may not conclude that they have a better learning experience if instructors are minimally involved in discussions.

Faculty preparation for shifting to a DL environment is essential. Faculty move from being the sage on the stage to the guide on the side and that this shift requires new ways of thinking about our teaching as well as new skills ${ }^{(13-15)}$. In a study involving roles experienced by faculty members as they move from classrooms to on-line environments changes were found in cognitive, affective and managerial roles. The cognitive role shifts to one of deeper cognitive complexity; the affective role requires faculty to become more comfortable with more intimate roles with students and to find new ways to express emotion; the managerial role requires more student monitoring, more attention to detail and provision of structure. The assumption that instructors can make these types of shifts immediately, and on their own, is unrealistic. It is necessary to prepare faculty members through mentorship and technical assistance ${ }^{(15,16)}$.

\section{STUDENT SUPPORT}

In an on-campus program, there are a variety of supports available that are not readily accessible to students who live at a distance. $M$ any distance students have been away from the academic environment for many years and need substantial assistance in developing their writing skills to meet the expectations. M ost students, with the right supports, can dramatically improve their writing skills, but this takes a great deal of time and effort on the part of both students and faculty members. This example is a challenge to be overcome.

In Brazil, another challenge is the need to develop institutional $D L$ policies that could support both students and faculties. To date, D L programs have been developed by individuals as isolated activities, and are not common practice in the university. D L programs, to be effective, should be integrated into an overall U niversity strategy for on-line learning to ensure that adequate support is available for the delivery of the program as well as student support services.

\section{CONCLUSIONS}

We are convinced that $D L$ graduate education in nursing has many benefits for students and enables many to engage in educational programs that they would otherwise be unable to complete. H owever, we have encountered some challenges with perhaps too much flexibility, supervising practice courses, facilitating interaction while balancing faculty workload, and the need for student support services. To ameliorate these challenges, we are engaged in ongoing faculty development, student orientation, policy development, and evaluation to continually improve quality and address issues. Students report high levels of satisfaction with the programs. Faculty and staff continue to strive for excellence in these educational programs, and despite challenges, continue to support flexible innovative g raduate education programs.

\section{REFERENCES}

1 Hopcraft A. E-learning and educational diversity: a response to Dawn Foreman et al. [ commentary] . N urse E duc T oday. 2002;22(1):83-4.

2 Baker W, Hale T, G ifford BR. From theory to implementation: the mediated learning approach to computer-mediated instruction, learning and assessment. E ducom Review. 1997;32(5):42-8.

3 Forman $D, N$ yatanga L, Rich T. E-learning and educational diversity. N urse E duc Today. 2002;22 (1):7682. 
4 Rodrigues RCV, Peres H HC. Panorama brasileiro do Ensino de Enfermagem on line. Rev Esc Enferm USP. 2008:42(2):298-304.

5 Silva VR, Silva M G, Santos L BO. Proposta pedagógica do PROFAE na perspectiva dos enfermeiros instrutores. Rev Bras Enferm. 2005;58(3):284-9.

$6 \mathrm{M}$ elrose S, Bergeron $\mathrm{K}$. Online graduate study or health care learners' perceptions of instructional immediacy. Int Rev Res Open D ist Learn. 2006;7(1): 1-13.

$7 \mathrm{G}$ amroth L, Sheilds L, Brown M . N urse Practitioner Program Evaluation Report. U npublished report, University of Victoria, British Columbia; 2005.

8 Kearns L, Shoaf J, Summey M . Performance and Satisfaction of Second-D egree BSN students in W ebbased and $T$ raditional Course D elivery $E$ nvironments. J N urs E duc. 2004;43(6):280-5.

9 Schon DA. The reflective practitioner: how professionals think in action. N ew York: Basic Books; 1983.

10 Andersen KM , Avery M D. Faculty teaching time: a comparison of web-based and face-to-face graduate nursing courses. Int J N urs E duc Scholarsh. 2008;5 (1):1-12.

\section{Endereço da autora / Dirección del autor / Author's address:}

A nita M olzahn

Faculty of Nursing, Floor Clinical Sciences Building, University of Alberta

Zip Code T 6G 2G 3, Edmonton, Alberta, Canada

E-mail:anita.molzahn@ualberta.ca
11 K ennedy D M . dimensions of distance: a comparison of classroom education and distance education. N urse E duc Today. 2002;22(5):409-16.

12 Blignaut S, T rollip SR. Developing a taxonomy of faculty participation in asynchronous lear ning environments: an exploratory investigation. Comput E duc. 2003;41(2):149-72.

13 M azzolini M , M addison S. Sage, guide or ghost? T he effect of instructor intervention on student participation in online discussion forums. Comput Educ. 2003;40(3):237-53.

$14 \mathrm{~T}$ homas $\mathrm{C}$. On line or face-to-face: which is the better way to talk? [ Internet] . L awrenceville: Peterson's; [ 200-] [ cited 2007 Oct 12] . Available from: http:// iiswinprd03.petersons.com/ distancelearning/ code/ articles/ distancel earnface7.asp.

15 Coppola N W, Hiltz SR, Rotter N G. Becoming a virtual professor: pedagogical roles and asynchronous learning networks. J M anage Inf Syst. 2002;18(4): 169-89.

16 Alves RHK, Cogo ALP. Vivência de estudantes de licenciatura em enfer magem em disciplina na modalidade à distância. Rev G aúcha Enferm. 2008;29(4): 626-32.

Recebido em: 20/ 05/2009

A provado em: 21/ 12/ 2009 